«Epistemological studies in Philosophy, Social and Political Sciences», 2018, 1 (1-2)

ISSN 2618-1274 (print) ISSN 2618-1282 (online)

УДК 327

Received 29 May 2017

Muradov I.

Received in revised form 30 June 2017

Middle East Technical University

Accepted 11 August 2017

\title{
THE IMPACT OF NATO ENLARGEMENT ON UKRAINE CRISIS: NEOREALIST PERSPECTIVE
}

This article introduces a new perspective to address the relationship between NATO enlargement policy and Ukraine Crisis. To simplify ongoing discussion on this subject, this particular research study utilizes two stripes of neorealism: offensive and defensive realism. Proponents of enlargement policy have been put into the offensive realists' side whereas opponents of it are placed in defensive realist camp. This article argues that each of these paradigms pose danger for Ukraine Crisis. Therefore, it adopts a middle way between offensive and defensive realism in terms of Ukraine issue.

Keywords: NATO, Ukraine Crisis, offensive realism, defensive realism

\section{Мурадов І., Вплив розширення НАТО на кризу в Україні: неореалістична перспектива}

Ця стаття представляє нову перспективу щодо відносин між політикою розширення НАТО та кризою України. Для спрощення поточної дискусії з цього питання, це конкретне дослідження використовує дві смуги неореалізму: наступальний та оборонний реалізм. Прихильники політики розширення були введені в сторону наступальних реалістів, тоді як противники іiі розміщуються в оборонний реалістичний табір. Ця стаття стверджує, що кожна з цих парадигм становить загрозу для кризи в Україні. Тому він приймає середній шлях між наступальним та оборонним реалізмом з точки зору проблеми України.

Ключові слова: НАТО, криза в Україні, наступальний реалізм, оборонний реалізм

\section{Мурадов И., Влияние расширения НАТО на кризис в Украине: неореалистическая пер- спектива}

Эта статья представляет новую перспективу в отношениях между политикой расширения НАТО и кризисом Украине. Для упрощения текущей дискуссии по этому вопросу, это конкретное исследование использует две полосы неореализма: наступательный и оборонительный реализм. Сторонники политики расширения были введены в сторону наступательных реалистов, тогда как противники ее размещаются в оборонительный реалистичный лагерь. Эта статья утверждает, что каждая из этих парадигм представляет угрозу для кризиса в Украине. Поэтому он принимает средний путь между наступательным и оборонительным реализмом с точки зрения проблемы Украины.

Ключевые слова: НАТО, кризис в Украине, наступательный реализм, оборонительный реализм 


\section{Introduction}

Ukraine Crisis in 2014 triggered pre-existent debate about the policy of NATO in post-Cold War period. Scholars and policymakers have been divided into two camps: one side insists on open-door policy of NATO (the right of every country to freely choose its alliance), the other side puts forward a recommendation to cease present policy and halt the expansion strategy of NATO to prevent the emergence of more conflicts in Europe. Advocates of open-door policy and thereby NATO enlargement believes that countries are free to shape their foreign policy directions. Moreover, they think it is the only option to deter Russian aggression in postSoviet space. The opponents of these arguments see NATO's expansion policy let alone a remedy for conflicts as a main cause for instability in Europe.

This article addresses the ongoing discussions about the connection between NATO enlargement policy and Ukraine Crisis. By assessing the subject through two branches of neorealism (offensive and defensive) the article aims to simplify comprehension of the puzzle. Therefore, first, the research scrutinizes offensive and defensive realism. Second, it assesses the relations between NATO enlargement and Ukraine Crisis through the lenses of offensive and defensive realism. Prospective conclusions for each paradigm (if any of them is implemented) are presented. Considering the risks of these conclusions the article argues that a via media needed to cope with the NATO enlargement issue and Ukraine Crisis.

Theoretical Framework: Offensive and Defensive Realism

Although both, classical and structural realism, adopt the power as a currency of international relations and use power politics as a synonym of international politics, they apart from each other in answering a simple but significant question: Why do states pursue power? The answer is clear for classical realists, such as Hans Morgenthau, that states desire power because of human nature ${ }^{1}$. However, for structural realists, human nature does not play a significant role in making states obsessed with power. Instead, it is the structure of international system forces states to pursue power. In international system, where there is no higher authority than states, there is no guarantee that one state will not attack another. Furthermore, structural realism makes crystal clear difference between domestic and international politics.

While neorealists agree on its basics, they also have divisions within neorealism. As it is mentioned above, distinctive characteristic of neorealists from classical realists appears in answering the question: Why states pursue power? Furthermore, there is a significant division among neorealists thinkers which arises from the question of How much power is enough? Mearsheimer defines Waltz's realism as a defensive realism. This assumption of Mearsheimer originates from Waltz's argument that pursuing too much power is risky. Maintaining to seek power will be punished by the structure of international system. In this case, Waltz points out that the pursuing hegemony is especially dangerous and foolhardy. Waltz, in his work titled "Structural Realism after the Cold War" criticizes the existence of NATO after the Cold War period ${ }^{2}$. In this article, Waltz emphasizes the durability of structural realism in changing international order within the system. According to the conditions of structure, Waltz implies, theory can be reviewed. 'Changes of the system' and 'changes in the system' should not be confused. "Within-system changes take place all the time, some important, some not. Big changes in the means of transportation, communication, and war fighting, for example, strongly affect how states and other agents interact ${ }^{3}$." These are the changes which take place at the unit level. In contrast, if structure of international politics change, then we may need a new theoretical framework to comprehend it. For instance, if one

\footnotetext{
${ }^{1}$ John J. Mearsheimer, "Sturctrual Realism," in International Relations Theories Discipline and Diversity, ed. Tim Dunne, Milja Kurki, and Steve Smith (Oxford: Oxford University Press, 2013), 77.

2 Kenneth N. Waltz, "Structural Realism after the Cold War," International Security 25, no. 1 (2000): 5-41, doi:10.1162/016228800560372.

${ }^{3}$ Ibid., 5.
} 
talks about 'world politics' or 'global politics' it means self-interested states that concerned with their own security issues has been replaced by a new kind of politics ${ }^{4}$. However, the anarchic nature of international system has not changed with the disintegration of Soviet Union. Therefore, neorealism is relevant for explaining post-Cold War period. As it is pointed above, for Waltz, too much power is dangerous for great powers and following hegemony particularly can be the worst scenario. Seeking for more power will end up with disaster due to the punishing principle of international structure. Mearsheimer claims that there are three basic reasons for defensive realists to see state's foolish strategy when they look for hegemony even if the structure of international system provides such opportunity ${ }^{5}$. First, states do not want to face hegemonic power because of survival issue. Therefore, other great powers tend to balance international system by creating ally against the hegemonic power. Napoleonic France (1792-1815), Imperial Germany (1900-18), and Nazi Germany (1933-45) are clear examples of this condition when these states attempted to dominate Europe. Each attempt had been defeated by an alliance that was composed by almost all other great powers. Hence, Otto von Bismarck was a genius who understood that too much power will not be in favor of Germany, the other great power can make balance against it. Thus, he wisely stopped the expansion of the country after the spectacular victories in the Austro-Prussian (1866) and Franco-Prussian (1870-1) Wars ${ }^{6}$. Second, defensive realists argue that there is an offence-defence balance that indicates how easy or difficult is to make benefit by conquering a territory. They claim that offence-defence balance is usually end up in favor of defender and thus the state which attacks the other to gain additional power find itself "fighting a series of losing wars" ". Third, defensive realists point out that even in the circumstances of successful conquest, victorious does not win in long period. In this sense, defensive realists emphasize the significance of nationalism ${ }^{8}$. This strong ideology is all about self-determination which guarantees that people of occupied territory will revolt against occupying state. In each of these scenarios, attempts to gain extra power brings disaster for states. From this point of view, evaluation of NATO enlargement policy by Kenneth Waltz who has been presented here as a defensive realist is quite interesting. The NATO as a collective security organization which was created by the Western bloc against Soviet threats was a product of the Bipolar World Order ${ }^{9}$. Waltz, first, emphasizes the maintenance of NATO's existence after the Cold War by transforming its mission shows the weakness of liberal approach. For Waltz, liberalist thinkers have difficulties to explain the existence of NATO because they forget the main point: institutions do not have autonomous, they are created by states to serve their interests. Contrary to the belief of liberalist thinkers, international institutions are not multilateral entities but tools of the main international actors ${ }^{10}$.

In contrast, as a defensive realist, Waltz does not support expansion of NATO. As it is pointed above, pursuing too much power is a dangerous policy for Waltz and he thinks that desire for to become a hegemon is a foolish strategy. On one hand the existence of NATO after the Cold War supports the theory of structural realism but on the other hand, expansion of NATO is perceived as a risky policy by Waltz. Enlargement of NATO following the disintegration of Warsaw Treaty Organization (established in 1955) causes new divisions in Europe that alienates states which left out. Waltz particularly emphasizes the possible effects of NATO enlargement policy on Russian Federation. It influences Russian people who tend to liberal democracy and market economy

\footnotetext{
${ }^{4}$ Ibid., 6.

${ }^{5}$ Mearsheimer, "Sturctrual Realism.", 81.

${ }^{6}$ Ibid.

${ }^{7}$ Ibid.

${ }^{8}$ Ibid.

9 Stephanie Lawson, Theories of International Relations (Cambridge: Polity Press, 2015), 100.

${ }^{10}$ Waltz, "Structural Realism after the Cold War", 20.
} 
and strengths the groups who consider the West as a main threat to their state interest. Russia has good reasons not to trust NATO (Russia has been attacked by the West throughout modern history) and Russians are aware that as an old member of Warsaw Pact NATO will not accept Russia as a new member ${ }^{11}$.

Nevertheless, offensive realists reject these arguments which are claimed by defensive realists. Mearsheimer presents one of the most pessimist version of structural realism. He accuses defensive realism due to containing certain optimistic views. Indeed, Mearsheimer argues that his proposed model of realism is much more 'realistic'. First, though threatened states establish balance against aggressive power, the coalition is often inefficient. Inefficiency of balance encourages and presents new opportunities for invader. "Furthermore, threatened states sometimes opt for buck-passing rather than joining a balancing coalition. In other words, they attempt to get other states to assume the burden of checking a powerful opponent while they remain on the sidelines. This kind of behavior, which is commonplace among great powers, also creates opportunities for aggression ${ }^{12}$." They also rejects the argument that defender has advantage over attacker. Mearsheimer strengthens his position by claiming that historical records show that the state which initiates war triumphs more than it loose. Moreover, though it is difficult to achieve hegemony the USA attained in the western hemisphere during nineteenth century. In the case of ideology, offensive realists accept the strength of nationalism, but they do not believe that it is an obstacle for occupier. Mearsheimer asserts Germany's occupation of France during the World War II as an example to this argument. Last, though offensive realists acknowledge that sometimes conquest does not pay they also claim that sometimes it does. Conquerors can exploit the economy of defeated state and can make huge profit on that ${ }^{13}$.

${ }^{11}$ Waltz, "Structural Realism after the Cold War", 22.

${ }^{12}$ Mearsheimer, "Sturctrual Realism.”, 81.

${ }^{13}$ Ibid., 82-83.

${ }^{14}$ John J. Mearsheimer, The Tragedy of Great Power Politics, (New York: W. W. Norton \& Company, 2001), 23-24.

${ }^{15}$ Mearsheimer, The Tragedy of Great Power Politics, 29-30.
My theory of offensive realism is also a structural theory of international politics. As with defensive realism, my theory sees great powers as concerned mainly with figuring out how to survive in a world where there is no agency to protect them from each other; they quickly realize that power is the key to their survival... For defensive realists, the international structure provides states with little incentive to seek additional increments of power; instead it pushes them to maintain the existing balance of power... Offensive realists, on the other hand, believe that status quo powers are rarely found in world politics, because the international system creates powerful incentives for states to look for opportunities to gain power at the expense of rivals, and to take advantage of those situations when the benefits outweigh the costs. A state's ultimate goal is to be the hegemon in the system ${ }^{14}$.

Mearsheimer propose five assumptions for the question that "Why states pursue power". The first one is that international system is anarchic (ordering principle of the system) where there is no higher authority above states. The second is that great powers possess military powers which constitute great dangers to each other. The third assumption is that of states' unpredictable intentions. States can never be certain that other states will not use their offensive military capabilities even if no threat is perceived because intentions of states can change quickly which make them unreliable to each other. The fourth assumption is that survival is the main goal of states in international arena. Particularly, states aim to preserve their sovereignty to maintain their territorial integrity and the domestic political order. Mearsheimer's last assumption is that great powers are rational actors. They observe developments which take place in international system and make their strategies according to survive ${ }^{15}$.

Although Mearsheimer proposes his offensive realism to provide an answer for the question of 
"how much power is enough?" he blames West in the case of Ukraine Crisis. In his article titled "Why the Ukraine Crisis Is the West's Fault" he argues that NATO enlargement along with the EU's Eastern Partnership program created this crisis. "The crisis there shows that realpolitik remains relevant - and states that ignore it do so at their own peril. U.S. and European leaders blundered in attempting to turn Ukraine into a Western stronghold on Russia's border. Now that the consequences have been laid bare, it would be an even greater mistake to continue this misbegotten policy ${ }^{16}$." This argument creates a contradiction between his previous arguments. As it is pointed above, according to Waltz pursuing too much power will be a foolish strategy for great power because states will establish coalition against aggressive state and desire for more power will bring disaster for it. In contrast, Mearsheimer proposes in his offensive realism that states should pursue power to achieve hegemony. However, in this aricle, Mearsheimer finds the NATO enlargement policy as a main cause of Ukraine Crisis and argues that continuation of this policy would be 'greater mistake'. Despite his defensive realist attitude in the case of Ukraine Crisis Mearsheimer stands in offensive realist camp different from Waltz who belongs to defensive realist group.

NATO Enlargement and Ukraine Crisis: Offensive or Defensive Realism?

Despite the analyses which revealed the connection between NATO's open-door policy and Ukraine Crisis NATO does not take any responsibility in this issue. Reisinger and Goltz assert that European Union's Association
Agreement with Ukraine triggered the crisis in Ukraine not NATO enlargement ${ }^{17}$. For Snegovaya, the crisis has nothing to do with Ukraine-NATO relations. Ukraine's relations with the EU was the main motivation or fear behind Kremlin's attitude for annexation of Crimea and destabilizing the Eastern Ukraine. "Democratic change in brotherly Ukraine could therefore spread to Russia' ${ }^{18 "}$. While explaining the effect of EU's intention in the sense of economic cooperation with Ukraine, Maximilian Klotz finds no reason for Kremlin to worry about it. Although it seems eastward enlargement of the EU weakens Russian economy, Moscow showed no compliant about this process ${ }^{19}$. However, European Neighborhood Policy aims to strengthen civil society organizations and thereby constitutionality and human rights in Ukraine. "The spread of these norms can be regarded as a (political) threat to Putin's regime in Russia, because Putin is fighting precisely against these elements in his own country ${ }^{20}$." In this case, annexation of Crimea and war in Eastern Ukraine can be explained as a "counter-color revolution" by Moscow ${ }^{21}$.

Right after the Russian actions in Ukraine some U.S. observers and the Members of Congress supported NATO enlargement policy particularly to the East. They believe that continuation of NATO's expansion is an important signal for likely members that, in the face of Russian opposition, NATO's open-door policy will not be changed. Some other proponents of the enlargement policy consider that Russia would not follow aggressive foreign policy if Ukraine was the member of the alliance $^{22}$. Another scholar, Michael Rühle, shed

\footnotetext{
16 John J. Mearsheimer, "Why the Ukraine Crisis Is the West's Fault," Foreign Affairs, no. February (2014): 2, doi:10.1017/CBO9781107415324.004.

${ }^{17}$ H. Reisinger and A. Golts, "Russia's Hybrid Warfare: Waging War below the Radar of Traditional Collective Defence," NATO Defense College, no. 105 (2014): 1.

${ }^{18}$ Maria Snegovaya, “Ukraine's Crisis Is Not the West's Fault," The Moscow Times, 2014, https://themoscowtimes. com/articles/ukraines-crisis-is-not-the-wests-fault-39411.

${ }^{19}$ Maximilian Klotz, "Russia and the Ukrainian Crisis: A Multiperspective Analysis of Russian Behaviour, by Taking into Account NATO's and the EU's Enlargement," Croatian International Relations Review 23, no. 80 (2017): 275, doi:10.1515/cirr-2017-0028.

${ }^{20}$ Ibid., 276.

${ }^{21}$ Reisinger and Golts, "Russia’s Hybrid Warfare: Waging War below the Radar of Traditional Collective Defence.", 3.

${ }^{22}$ Paul Belkin, Derek E Mix, and Steven Woehrel, "NATO: Response to the Crisis in Ukraine and Security Concerns in Central and Eastern Europe," Congressional Research Service Report, 2014, 16.
} 
lights on the influence of NATO's enlargement policy on Ukraine Crisis. He, first, attempts to disprove Russian arguments in terms of NATO's "promise" on its expansion policy after the unification of Germany which is the main narrative of Russian politicians regarding with the West. Rühle emphasizes "there have never been political or legally binding commitments of the West not to extend NATO beyond the borders of a reunified Germany, nor has there ever been a concrete invitation to Russia to join $\mathrm{NATO}^{23}$." He recommends NATO to update its threat perception according to current conflicts. Rühle suggests that NATO should review its political declaration, made in 1997 in frame of NATO-Russia Founding Act, about assessing "no need for deployment of substantial combat forces on the territory of Eastern Europe...this [declaration] were made under the condition that Russia would also show military restrain ${ }^{24}$."

To sum up, proponents of the NATO's enlargement process can be viewed in the context of aforementioned offensive realists. They believe that international actors should seek for power as much as they can. Only in this condition they can guarantee their survival in international system. In terms of NATO expansion, halting the opendoor policy will encourage Russia to dominate its 'near abroad'.

In contrast, opponents of the enlargement policy claim that NATO's extension to eastward causes instability in the region. For Dmitri Trenin, the origin of Ukraine Crisis goes back to 2008 Russian-Georgian War which prevented the prospect expansion of NATO for both Ukraine and Georgia ${ }^{25}$. Another thinker Elias Götz, asserts that Ukraine Crisis stemmed from the external threat which was perceived by Russia. Götz points out that when great actors feel high level of external pressure in their 'near abroad' they react with military power. From this point of view, Götz claims that NATO enlargement policy caused Ukraine Crisis ${ }^{26}$. Shifrinson, another scholar, points the risks of deterring Russia by strengthening NATO's presence in Eastern Europe. NATO's opendoor policy will eventually lead to deepen the Russian insecurity ${ }^{27}$.

Bjørn Olav Knutsen assesses Ukraine Crisis as an indication of multipolar world system. For Knutsen NATO enlargement policy has been stopped by Russia. This shows the emergence of "a multipolar order where the Western values do not seem to have the same universal appeal anymore ${ }^{28}$ ". Knutsen claims, in this circumstance, Ukraine will for the foreseeable future remain in intermediate condition. Contrary to Knutsen's arguments, Trenin evaluates Ukraine Crisis as a sign of revealing balanced international system between the USA and Russia. However, Trenin also comes up with a result which see Ukraine in an intermediate state between West and Russia and do not expect an end for the conflict in the foreseeable future ${ }^{29}$. Different from Knutsen and Trenin, Donaldson argues that the Ukraine Crisis takes its source from misperceptions on both sides: "by Russian perceptions of security challenges resulting from NATO's enlargement, as Moscow reacted (and over-reacted) to the threat that Ukraine would become a member and, as such, would pose a danger to Russia; and (2) by Western blindness to (or lack of concern for) the genuine worries that the prospect of Ukrainian membership stirred

\footnotetext{
${ }^{23}$ Michael Rühle, "NATO Enlargment and RUssia: Die-Hard Myts and Real Dilemmas,” 2014, 2.

${ }^{24}$ Ibid., 6.

${ }^{25}$ Dmitri Trenin, “The Ukraine Crisis and the Resumption of Great-Power Rivalry," Carnegie Endowment July 09 (2014): 4, http://www.carnegie.ru/2014/07/09/ukraine-crisis-and-resumption-of-great-power-rivalry/hfgs\#.

${ }^{26}$ Elias Götz, "Neorealism and Russia's Ukraine Policy, 1991-present," Contemporary Politics 22, no. 3 (2016): 301-23, doi:10.1080/13569775.2016.1201312.

${ }^{27}$ Joshua R. Itzkowitz Shifrinson, "Deal or No Deal? The End of the Cold War and the U.S. Offer to Limit NATO Expansion," International Security 40, no. 4 (2016): 43, doi:10.1162/ISEC.

${ }^{28}$ Bjørn Olav Knutsen, "How Has the Ukrainian Issue Reshaped the NATO Alliance ?," Norwegian Defence Research Establishment, 2015, 5.

${ }^{29}$ Trenin, "The Ukraine Crisis and the Resumption of Great-Power Rivalry.”, 26.
} 
in Russian minds ${ }^{30}$." Donaldson draws attention to new security agenda in Europe which should be inclusive rather than exclusive in the case of Russia $^{31}$. Only if Russia is convinced that NATO enlargement is not a threat to it, the Ukraine crisis can be solved.

A well-known figure in international relations, former American diplomat and historian George F. Kennan, once foresightedly claimed that NATO expansion could be a "fateful error". For Kennan, "such a decision may be expected to inflame the nationalistic, anti-Western and militaristic tendencies in Russian opinion; to restore the atmosphere of the cold war to East-West relations, and to impel Russian foreign policy in directions decidedly not to our liking". 32 Another prominent thinker, Henry Kissenger, warns policymakers about NATO's eastward expansion particularly against prospective Ukraine membership. For Kissenger, though Ukraine is a sovereign country and can make its foreign policy choose NATO should also take Russian security concerns into account during the negotiations with Ukraine ${ }^{33}$.

Scholars who see the NATO enlargement as a cause of Ukraine Crisis can be included among defensive realists which is explained above. These thinkers believe that structure of international system punish the states which seek to gain more power. As a stripe of neorealist paradigm, they claim that final goal of states in international relations is survival and for this very reason they pursue power. However, as it was mentioned in previous section, defensive realists do not acclaim state which pursue limitless power. Too much power will bring eventually disaster for a state due to a coalition of other states against it.

Implementing any of these paradigms, offensive realism and defensive realism, escalate the tension
Ukraine. As it is presented in the case of offensive realism, pursuing enlargement policy toward eastward particularly to Ukraine strengthen Russia's argument regarding to NATO's policy. Therefore, expansion policy provides reinforced alibi for Russian aggression in its 'near abroad'. On the contrary, taking step backward on enlargement policy, as defensive realist may suggest, will hearten Kremlin to constrain foreign policy of neighboring countries by using hard power. In this regard, it is better to adopt middle course between these two camps. After Georgia-Russian War in 2008, Rafael Biermann claimed that NATO enlargement policy has geographic limits. Any expansion beyond these limits will spawn new conflicts such as South Ossetia and Abkhazia. He proposed that on one hand NATO should reaffirm its open-door policy which underpin the right of every country to choose its alliance. On the other hand, NATO should declare that its enlargement policy has geographical limits and it will cease in the South Caucasus to "afford reassurance that NATO will not 'encircle' Russia". ${ }^{44}$ Alike argument has been made by Andrew T. Wolf. By Advancing the thesis of geographical limits of enlargement policy Wolf claims that NATO has geopolitical limits. He argues that Ukraine Crisis is the result of disagreement between liberal-minded West and geopolitically-minded Russia. For Wolf, to reduce the tension which arises from NATO enlargement policy, the West should admit the failure of NATO's open-door policy which created insecurity in Europe and should alter this policy by "injecting it with geopolitical reasoning". ${ }^{35}$ The author claims that though NATO's open-door policy for Ukraine is principally correct, geopolitically it is a mistake. For Wolf, NATO enlargement policy should be continued in Balkans and in Scandinavian countries $^{36}$. However, Ukraine membership is

${ }^{30}$ Robert H. Donaldson, "The Role of NATO Enlargement in the Ukraine Crisis," Soviet and Post Soviet Review 44, no. 1 (2017): 32, doi:10.1163/18763324-04401004.

${ }^{31}$ Ibid., 50 .

${ }^{32}$ George F. Kennan, “A Fateful Error,” The New York Times, 1997, https://www.nytimes.com/1997/02/05/opinion/afateful-error.html.

${ }^{33}$ H Kissinger, "How the Ukraine Crisis Ends," The Washington Post, 2014, http://scholar.google.com/scholar?hl=en $\& \mathrm{q}=\mathrm{ukraine}+\mathrm{crisis} \& \mathrm{btnG}=\&$ as_sdt=1,5\&as_sdtp=\#2.

${ }^{34}$ Rafael Biermann, "NATO Enlargement - Approaching a Standstill,” Security Insights 4, no. December 2009 (2009): 1-8.

${ }^{35}$ Andrew T. Wolff, "The Future of NATO Enlargement After the Ukraine Crisis," International Affairs 91, no. 5 (2015): 1104, doi:10.1111/1468-2346.12400.

${ }^{36}$ Ibid., 1117. 
geopolitical mistake and any attempt to advance this issue will bring more instability for the country.

\section{Conclusion}

In this article, it is attempted to explain the relations between NATO enlargement and Ukraine Crisis. Scholars mainly divided into two camps with respect to ongoing discussions in terms of this theme; one supports the NATO's open-door policy whereas the other finds enlargement policy very dangerous and the cause of current conflict in Ukraine. To have better understanding, this research paper gathered these two groups into two stripes of neorealism: offensive and defensive realists and claimed that neither paradigm can fully overcome the paradoxical relationship between NATO enlargement and Ukraine Crisis. If NATO's extension continues and reinforced its presence in Ukraine, as may propose by offensive realists, Ukraine Crisis will be escalated even more, and country's eastern part will be turned to another 'frozen conflict' in post-Soviet space. In contrast, halting the enlargement policy in the face of Russian aggression in Ukraine can encourage Russia even more to use military force in its 'near abroad'. For these reasons neither approaches are compatible to cope with the ongoing crisis. However, using both views partly help to come up with a solution for the puzzle. Currently, ensuring the territorial integrity of Ukraine should be prioritized, and for this purpose, NATO enlargement policy should not be used to deter Russia (which indeed escalates the war in Eastern Ukraine) instead NATO membership option for Ukraine should be used as a leverage in peace process to ensure territorial integrity of Ukraine.

\section{References}

1. Belkin, Paul, Derek E Mix, and Steven Woehrel. "NATO: Response to the Crisis in Ukraine and Security Concerns in Central and Eastern Europe.” Congressional Research Service Report, 2014, 1-20.

2. Biermann, Rafael. "NATO Enlargement - Approaching a Standstill.” Security Insights 4, no. December 2009 (2009): 1-8. 3. Donaldson, Robert H. "The Role of NATO Enlargement in the Ukraine Crisis." Soviet and Post Soviet Review 44, no. 1 (2017): 32-52. doi:10.1163/18763324-04401004.

4. Götz, Elias. "Neorealism and Russia’s Ukraine Policy, 1991-present.” Contemporary Politics 22, no. 3 (2016): $301-23$. doi:10.1080/13569775.2016.1201312.

5. Kennan, George F. “A Fateful Error.” The New York Times, 1997. https://www.nytimes.com/1997/02/05/opinion/afateful-error.html.

6. Kissinger, H. "How the Ukraine Crisis Ends." The Washington Post, 2014. http://scholar.google.com/scholar?hl=en\&q $=$ ukraine+crisis\&btnG $=\&$ as_sdt $=1,5 \&$ as_sdtp $=\# 2$.

7. Klotz, Maximilian. "Russia and the Ukrainian Crisis: A Multiperspective Analysis of Russian Behaviour, by Taking into Account NATO's and the EU's Enlargement." Croatian International Relations Review 23, no. 80 (2017): $259-87$. doi:10.1515/cirr-2017-0028.

8. Knutsen, Bjørn Olav. "How Has the Ukrainian Issue Reshaped the NATO Alliance ?" Norwegian Defence Research Establishment, 2015.

9. Lawson, Stephanie. Theories of International Relations. Cambridge: Polity Press, 2015.

10. Mearsheimer, John J. "Sturctrual Realism." In International Relations Theories Discipline and Diversity, edited by Tim Dunne, Milja Kurki, and Steve Smith, 77-91. Oxford: Oxford University Press, 2013.

11. The Tragedy of Great Power Politics. Statewide Agricultural Land Use Baseline 2015. Vol. 1. New York: W. W. Norton \& Company, 2001. doi:10.1017/CBO9781107415324.004.

12. "Why the Ukraine Crisis Is the West' s Fault." Foreign Affairs, no. February (2014): 1-21. doi:10.1017/ CBO9781107415324.004.

13. Reisinger, H., and A. Golts. "Russia's Hybrid Warfare: Waging War below the Radar of Traditional Collective Defence." NATO Defense College, no. 105 (2014): 1-8.

14. Rühle, Michael. "NATO Enlargment and RUssia: Die-Hard Myts and Real Dilemmas," 2014.

15. Shifrinson, Joshua R. Itzkowitz. "Deal or No Deal? The End of the Cold War and the U.S. Offer to Limit NATO Expansion.” International Security 40, no. 4 (2016): 27. doi:10.1162/ISEC.

16. Snegovaya, Maria. “Ukraine's Crisis Is Not the West's Fault." The Moscow Times, 2014. https://themoscowtimes. com/articles/ukraines-crisis-is-not-the-wests-fault-39411.

17. Trenin, Dmitri. "The Ukraine Crisis and the Resumption of Great-Power Rivalry." Carnegie Endowment July 09 (2014): 1-17. http://www.carnegie.ru/2014/07/09/ukraine-crisis-and-resumption-of-great-power-rivalry/hfgs\#.

18. Waltz, Kenneth N. "Structural Realism after the Cold War." International Security 25, no. 1 (2000): 5-41. doi:10.1162/016228800560372.

19. Wolff, Andrew T. “The Future of NATO Enlargement After the Ukraine Crisis.” International Affairs 91, no. 5 (2015): 1103-21. doi:10.1111/1468-2346.12400. 